\title{
Pelatihan Maintance Komputer SMK Negeri 3 Lahat
}

\author{
${ }^{1)}$ Yogi Isro Mukti, ${ }^{2)}$ Asep Syaputra \\ ${ }^{1,2}$ Program Studi Teknik Informatika; Sekolah Tinggi Teknologi Pagaralam \\ (STTP) Jl. M. Siagim No.75 Kel. Karang Dalo, Dempo Tengah, Kota Pagar \\ Alam Telp/Fax: (0730) 621916 \\ e-mail: ${ }^{1)}$ Yogie.Isro.mukti@gmail.com. ${ }^{2)}$ asepsyaputra68@gmail.com
}

\begin{abstract}
Abstrak
Perangkat keras komputer merupakan sistem yang harus di jaga sama pentingnya dengan perangkat lunak (software), keduanya sangat penting dan tidak bisa dipisahkan. SMKN 3 Lahat lembaga pendidikan menengah yang membantu pemerintah dalam menyiapkan generasi pemimpin pada masa mendatang, pelatihan maintenance komputer menjadi satu kegiatan atau usaha yang dilakukan SMKN 3 Lahat untuk menambah softskills siswa, terutama siswa yang siap menjadi Alumni, pelatihan dilakukan oleh Civitas STTP yang melakukan pengabdian, metode pelatihan dengan ceramah dan praktek secara langsung pada perangkat keras komputer. Pada awal pelatihan dilakukan tes untuk mengetahui pemahaman siswa peserta pelatihan pemahamannya terhadap perangkat keras komputer, dan hasilnya mereka tidak terlalu baik memahami perangkat keras komputer sehingga pelatihan harus dilakukan, pada akhir pelatihan dilakukan tes lagi untuk mengetahui tingkat keberhasilan pelaksanaan pelatihan, dan hasilnya karena mereka sudah memiliki dasar pemahaman tentang perangkat keras, tentang maintenance komputer sehingga dengan adanya pelatihan ini narasumber menjadi lebih mudah menyampaikan materi dan hasilnya setelah pelatihan para siswa peserta mampu mamahami materi dengan baik dan pelatihan berhasil menambah pengetahuan peserta pelatihan.
\end{abstract}

Kata kunci-Komputer, Pendidikan, Siswa, Maintenance, Peserta.

\section{PENDAHULUAN.}

Pengabdian merupakan kewajiban yang harus dilakukan civitas Perguruan Tinggi (PT) demikian halnya Sekolah Tinggi Teknologi Pagaralam (STTP) setiap semester mengadakan pengabdian, dalam pelaksanaannya. Kadang berbarengan dengan program kegiatan kuliah kerja nyata $(\mathrm{KKN})$ mahasiswa, pengabdian yang dilakukan oleh civitas STTP selalu berhubungan dengan keilmuan yang dimiliki yaitu teknologi informasi (TI), dimana TI saat ini menjadi hal yang sangat penting karena seluruh sisi kehidupan telah mengaplikasikan teknologi informasi. Karena dalam perkembangan teknologi informasi dan komunikasi (TIK) khususnya teknologi yang mendukung terlaksananya kegiatan (pendukung) pekerjaan inividu saat ini sangat banyak dan menawarkan kemudahan sesuai ke unggulan masing-masing, salah satunya teknologi sistem komputer ini bisa di manfaatkan untuk berbagai kegiatan, hampir tidak ada yang tidak bisa di kerjakan komputer, terbukti seluruh kegiatan manusia segala kegiatan, segala profesi sudah menggunakan komputer dan mengaplikasikan program tertentu dari mulai komputer atau program yang sederhana sampai dengan sistem komputer dan program dengan konfigurasi yang sangat kompleks, dari komputer yang tidak saling terhubung (personal), tergabung dalam jaringan LAN, MAN dan WAN, dari software hanya di aplikasikan satu PC sampai dengan sistem yang terdistribusi dan client server, tentunya itu semua untuk mendukung kegiatan manusia, untuk memudahkan.

Pelatihan pengelolaan sistem \& maintenance komputer merupakan pemberian pemahaman awal bagi pengelolaan komputer diharapkan walau pun siswa ini siswa daerah tetapi dapat mandiri, artinya diharapkan saatnya nanti turun di dunia kerja Alumni SMKN 3 Kab. Lahat ini tak hanya menjadi pemakai sistem komputer, tetapi selain pemakai pada saat terjadi kerusahan atau 
kekurangan yang terjadi pada sistem komputer mereka tidak tergantung pada pihak lain, dalam hal ini mampu menangani terlebih dahulu tanpa bantuan pihak lain, kecuali apa bila terjadi ke rusakan memerlukan penanganan khusus sebab itu maka pelatihan ini terlaksana, pada dasarnya seluruh sistem pembelajaran sudah termasuk tentang pengelolaan dan maintenance ini tetapi untuk memberikan kesempatan pada para dosen STTP untuk berbagi dan mungkin terdapat sesuatu yang terlewati atau terlupakan guru dalam kelas maka SMKN 3 Kab. Lahat menyambut baik terlaksananya pengabdian ini.

Selain itu kondisi geografis dan fasilitas teknologi informasi (TI) yang belum memadai di daerah Kab. Lahat berimbas pada tingkat pemahaman dan penalaran terhadap sesuatu hal baru agak terhambat, STTP sebagai Pionir dan dianggap lembaga kompeten terus mengikuti perkembangan teknologi informasi, dan kewajiban melakukan pengabdian seperti yang di amanatkan jargon Tri dharma, maka di adakan pengabdian yang kegiatannya pelatihan maintenance ini, sebenarnya upaya untuk berbagi dan saling memahamkan terhadap suatu ilmu yang di rasa Para siswa dan Guru SMKN 3 Kab. Lahat kurang. Dari pemaparan ini dituntut agar para siswa SMKN $3 \mathrm{Kab}$. Lahat harus selalu meningkatkan kualitas pemahaman terhadap Teknologi informasi dengan menggunakan semua resource terkait, sehingga dipandang perlu untuk diadakan pelatihan Maintenance di lingkungan SMKN 3 Kab. Lahat. Berdasarkan informasi yang diperoleh dari para siswa dan Guru SMKN 3 LAHAT, masalah yang dihadapi dapat diidentifikasikan sebagai berikut.

1. Para siswa belum terlalu memahami baik maintenance.

2. Para siswa belum memahamisistem perangkat keras komputer.

3. Para siswa belum terlalu memahami software dan tools maintenance lainnya

\section{METODE.}

Metode pelaksanaan pengabdian ini dilakukan dosen STTP dilaksanakan secara mandiri, dan berbarengan dengan kuliah kerja nyata $(\mathrm{KKN})$ yang dilakukan para mahasiswa sehingga dalam pelaksanaanya mahasiswa membantu dosen yang melaksanakan pengabdian di SMKN 3 Kab. Lahat. Pada pelaksanaan kegiatan Pengabdian kepada masyarakat $(\mathrm{PkM})$ ini adalah menyimak (menonton) bersama, membaca bersama (modul pelatihan), memahami tools aplikasi (Software) dan berinteraksi secara langsung (Aplikatif) dengan software. Dimana agar lebih efektif pada awal dan akhir kegiatan dilakukan tes.

\subsection{Pengabdian kepada Masyarakat (PkM).}

Pengabdian kepada masyarakat suatu kegiatan bertujuan membantu masyarakat tertentu di beberapa aktivitas yang berlainan tanpa mengharapkan imbalan. Secara umum program dirancang oleh lembaga penelitian dan pengandian pada masyarakat (LPPM) pada masyarakat, untuk memberikan kontribusi nyata kepada masyarakat, khususnya saat mengembangkan kesejahteraan dan kemajuan bangsa. Program kegiatan Pengabdian Masyarakat (PkM) ini merupakan salah satu bagian dari Tri Dharma Perguruan Tinggi. Bentuk-bentuk kegiatan Pengabdian Masyarakat, yaitu: Bakti Sosial dan Mengajar. Tujuan Pengabdian Masyarakat di Perguruan Tinggi, diantaranya:

1. Menciptakan jiwa yang mandiri dan memberikan manfaat yang nyata untuk masyarakat.

2. Meningkatkan inovasi teknologi untuk mendorong pembangunan dengan melakukan komersialisasi hasil penelitian, yang dilakukan dosen dan mahasiswa;

3. Mengupayakan solusi berdasarkan kajian akademik atas kebutuhan, tantangan, atau persoalan yang dihadapi masyarakat, baik secara langsung maupun tidak langsung;

4. Melaksanakan kegiatan yang mengentaskan masyarakat tersisih (preferential option for the poor) semua strata, yaitu masyarakat tersisih secara ekonomi, politik, sosial, dan budaya;

5. Melakukan alih teknologi, ilmu, dan seni kepada masyarakat untuk pengembangan martabat manusia dan kelestarian sumber daya alam.

\subsection{Teknologi Informasi (TI).}

Kata Teknologi Informasi (TI) berasal dari kata Information Technology (IT). Kata Technology berdasarkan Kamus Advanced Leaner's Dictionary of Current English (1974) adalah penerapan pengetahuan secara sistematis pada tugas praktis dalam suatu industri. Senada dengan definisi itu, Sulistyo-Basuki (1992:81) menyatakan Teknologi diartikan sebagai pelaksanaan ilmu, 
sinonim dengan ilmu terapan. Kata Informasi di Oxford Advanced Learners's Dictionary of Current English (1980: 437), diartikan sesuatu yang diberitahukan, pengetahuan dan berita. Sedang Ilmu Informasi, kata "Informasi", "pengetahuan", dan "berita" dibedakan. Menurut Teskey (Pendit,1992) data adalah hasil observasi langsung terhadap suatu kejadian, merupakan perlambangan mewakili objek atau konsep di dunia nyata, dilengkapi nilai tertentu; Informasi adalah kumpulan data terstruktur, disampaikan seseorang pada orang lain. Sedangkan berita menurut Arifin (1997), adalah informasi menarik, penting dan belum pernah didengar. Informasi merupakan sarana untuk menunjang dan meningkatkan kegiatan bidang Ilmu Pengetahuan, kebudayaan dan teknologi. Pengetahuan adalah sesuatu digunakan manusia untuk memahami dunia, yang bisa diubah berdasarkan informasi yang diterima. Pada laporan ini informasi secara singkat diartikan sebagai segala data, fakta \& pengetahuan disampaikan pada orang melalui berbagai media, dalam bentuk tekstual, gambar, maupun suara.

Teknologi informasi (TI) sebuah istilah baru merupakan terjemahan dari Information Technology bagi kebanyakan orang teknologi informasi merupakan sinonim dari "Teknologi Baru", karena kaitannya erat dengan mesin microprosesor, seperti mikro-komputer, alat yang bekerja otomatis, seperti alat pengolah kata, dan lain sebagainya . Pengertian Teknologi Informasi berdasarkan British Advisory Council for Applied Research and Development (Zorkoczy, (1990:

12) adalah meliputi bidang ilmu pengetahuan, teknologi dan perekayasaan serta teknik pengelolaan yang digunakan pada penanganan dan pengolahan informasi, penerapan bidang dan teknik tersebut, komputer dan interaksi dengan manusia dan mesin, masalah sosial ekonomi serta budaya yang berkaitan. Memang banyak definisi tentang Teknologi Informasi, sehingga dalam "Macmillan Dictionary of Personal Computing and Communication" terdapat empat halaman menjelaskan Teknologi Informasi.

\subsection{Maintenance.}

Pengertian maintenance merupakan kegiatan pemeliharaan dan perbaikan jika ada harus yang di perbaiki terhadap suatu perangkat atau sistem tertentu, dalam hal ini merupakan sistem komputer, maintenance merupakan pemeliharaan atau perbaikan rutin, dengan adanya maintenance sistem komputer atau jaringan komputer bisa terhindar dari kerusakan sangat parah, karena terjadi kerusakan, hal yang tidak diinginkan terjadi pada sistem komputer telah diantisipasi dahulu.

\subsection{Pre \& Pos Tes.}

Pernyataan Pre tes yaitu suatu bentuk pertanyaan, yang dilontarkan para pengajar kepada peserta didiknya sebelum memulai suatu pelajaran atau materi yang disampaikan. Pertanyaannya ditanya adalah materi akan diajarkan hari itu (materi baru). Pertanyaan biasanya dilakukan pengajar di awal pembukaan pelajaran. Pre tes diberikan dengan maksud mengetahui apakah ada di antara pelajar yang telah mengetahui mengenai materi akan diajarkan. Pre tes juga di artikan kegiatan menguji tingkatan pengetahuan pelajar terhadap materi akan disampaikan, kegiatan pre tes dilakukan sebelum kegiatan pengajaran dilaksanakan. Adapun manfaat diadakannya pre tes untuk mengetahui kemampuan awal mengenai pelajaran yang disampaikan. Dengan mengetahui kemampuan awal pelajar, pengajar dapat menentukan cara penyampaian pelajaran yang di tempuhnya nanti.

Pos tes merupakan bentuk pertanyaan yang diberikan setelah pelajaran/materi telah disampaikan. Singkatnya, pos tes adalah evalausi akhir saat materi di ajarkan pada hari itu telah diberikan yang mana pengajar memberikan pos tes dengan maksud apakah pelajar sudah mengerti dan memahami mengenai materi yang baru saja diberikan hari itu. Manfaat diadakannya pos tes ini untuk memperoleh gambaran tentang kemampuan yang dicapai setelah berakhir penyampaian pelajaran. Hasil dari pos tes ini dibandingkan dengan hasil pre tes yang telah dilakukan sehingga diketahui seberapa jauh efek atau pengaruh pengajaran yang dilakukan, disamping sekaligus dapat diketahui bagian mana dari bahan pengajaran yang masih belum dipahami sebagian besar pelajar.

\subsection{Penyelesaian Masalah.}

Sesui dengan permasalahan ini maka perlu dilakukan pelatihan maintenance komputer, ini di yakini bisa menambah softskills dan kepercayaan diri alumni SMKN 3 Lahat sehingga tidak hanya 
masalah atau pelajaran umum saja yang dipahaminya tetapi mendapat pelajaran tambahan dalam menghadapi perkembangan zaman pada masyarakat.

\section{PEMBAHASAN DAN HASIL.}

3.1. Realisasi \& Pemecahan Masalah.

Realisasi dan pemecahan permasalahan yang dihadapi SMKN 3 Kab. Lahat dalam menambah softskills siswa/siswinya dalam hal ini menambah softskills menambah pemahaman bidang mata pelajaran maintenance, dilakukan dengan mengadakan pelatihan bekerja sama dengan civitas akademika STTP yang sedang melaksanakan pengabdian untuk melakukan pelatihan dengan rincian kegiatan sebagai berikut: Pertama, dilaksanakan pre tes pada awal pelatihan untuk mengarahkan dan memberi gambaran kepada narasumber tentang arah penyampaian materi pelatihan sehingga materi yang disampaikan merupakan benar-benar materi yang diperlukan oleh peserta pelatihan. Kedua, Pengantar maintenance. Merupakan penjelasan awal tentang perangkat keras dan perangkat lunak sistem komputer yang umumnya mudah mengalami trouble jadi ini merupakan penjelasan awal tentang troubleshooting yang biasa atau sering terjadi pada sistem komputer. Ketiga Praktek, pada bagian ini merupakan bagian dimana siswa peserta setelah mengetahui dan memahami tentang troubleshooting, memahami secara langsung tips dan trik troubleshooting dengan mengenal keadaan atau kejadian yang memungkinkan ketika ada error pada komputer, ketika terjadi crass, error, damage dan kesalahan lain yang membuat komputer tidak berjalan. Keempat pos tes, dilakukan narasumber pada saat setelah pelatihan selesai dilaksanakan dan berhasil, pos tes dilakukan untuk melengkapi rasa keyakinan, atau lebih memantapkan rasa keyakinan jika pelatihan berjalan dengan lancar dan seluruh peserta menyerap materi dengan baik dan sesuai dengan yang diharapkan oleh terlaksananya pelatihan ini. Maka berdasarkan cara penyelesaian masalah yang dijadikan acuan, maka berikut merupakan langkahlangkah pelaksanaan pengabdian yang sudah dilakukan pengabdi, yang mana pada dilaksanakan secara berurut sebagai berikut:

Tabel 1. Rincian Kegiatan

\begin{tabular}{|c|l|c|}
\hline Waktu & \multicolumn{1}{|c|}{ Materi } & Penyaji \\
\hline $08.00-09.00$ & Pre Test & \\
$09.00-09.30$ & Pengantar Maintenance (pengenalan software \& hardware) & \\
\hline $09.30-12.00$ & $\begin{array}{l}\text { Pengantar troubleshooting dasar yang ada pada komputer dan } \\
\text { praktek instalasi }\end{array}$ & \multirow{2}{*}{ Yogi I. Mukti } \\
$12.00-12.30$ & Ishoma & \\
$12.30-13.00$ & Post-test & \\
\hline
\end{tabular}

Berdasarkan tabel 1, kegiatan yang dilaksanakan benar-benar terencana dan mengikuti aturan tertentu sesuai arahan dan pembekalan yang dilakukan LPPM sebelum penerjunan ke lapangan bahwa seluruh kegiatan yang dilakukan harus mengikuti aturan dan menggunakan metode yang jelas, agar kegiatan pengabdian berjalan dengan baik, dan memiliki perencanaan yang jelas, terukur dan terkontrol. Berdasarkan hal tersebut, pelatihan dimulai dengan pengukuran yaitu dengan pre tes diakhiri dengan pengukuran juga yaitu pos tes. Sehingga pelaksanaan kegiatan pelatihan benarbenar terlaksana berdasarkan pengawasan dan pengendalian yang baik. Sehingga output yang dihasilkan juga benar-benar baik, ini dilakukan karena pelaksanaan pengabdian menjadi ukuran dan citra STTP didepan masyarakat, desa binaan, kelompok binaan atau instansi binaan. Agar manfaat pelatihan bisa dirasakan oleh masyarakat. Tentu harapan akhirnya dari sini menumbuhkan rasa percaya kepada sistem pendidikan dan STTP secara umum sehingga menambah calon peserta didik yang masuk atau yang kuliah di STTP.

\subsection{Pembahasan \& Hasil.}

Subbagian 3.1 merupakan rincian kegiatan realisasi dan cara pemecahan permasalahan yang dilaksanakan untuk menjawab kebutuhan pemenuhan masalah yang dihadapi pihak SMKN 3 Kab. Lahat, pada bagian ini menjelaskan tentang keberhasilan dari pelaksanaan tersebut sesuai urutan pelaksanaan pada bagian 3.1 tersebut dimana urutan pelaksanaannya diawali dengan, Pertama: Pelaksanaan pre tes, hasilnya: peserta merupakan siswa dan siswi SMK sehingga pada 
dasarnya mereka telah memahami dengan baik teori tentang troubleshooting tetapi pada saat praktek langsung dengan komputer menurut mereka dari hasil pre tes ini terkadang merasa bingung dan kaku dengan sistem komputer sehingga dengan adanya pelatihan ini menambah dengan baik pemahaman yang sudah ada menjadi benar-benar menguasai troubleshooting dan maintenance yang ada pada komputer, sehingga troubleshooting sederhana dengan pelatihan ini peserta mampu dengan cepat memahami ketika ada crass, hang, damage dan sebagainya kerusakan awal peserta mampu mengatasi bahkan instalasi software bisa dilakukan dengan baik. Kedua pengantar maintenance dan troubleshooting, peserta memahami dengan baik secara teknis perangkat keras dan lunak yang ada pada sistem komputer. Ketiga, peserta mampu memperbaiki komponen yang rusak missal diakibatkan arus pendek dan lain-lain, atau melakukan pergantian komponen karena permasalahan lain, atau melakukan instalasi ulang karena berbagai masalah. Terakhir pos tes, pos tes dilakukan untuk mengetahui tingkat keberhasilan pelaksanaan pengabdian untuk menjadi masukan bagi penyelenggaraan pelaksanaan pengabdian pada periode-periode yang akan datang, dan secara umum kegiatan pengabdian yang dilaksanakan pada SMKN 3 Kab. Lahat berdasarkan tes-tes dan observasi yang dilakukan sangat memuaskan, berikut uraian jika dibuat dalam bentuk tabel, dideskripsikan pada tabel 2 dibawah ini:

Tabel 2. Keberhasilan Pelaksanaan Kegiatan

\begin{tabular}{|l|l|}
\hline \multicolumn{1}{|c|}{ Materi } & \multicolumn{1}{c|}{ Hasil } \\
\hline Pendahuluan & $\begin{array}{l}\text { Merupakan pelaksanaan pre tes dan hasilnya peserta secara praktek } \\
\text { masih merasa kekurangan karena kekurangan waktu didalam kelas } \\
\text { sehingga harus dilaksanakan pelatihan ini. }\end{array}$ \\
\hline Pengantar maintenance & $\begin{array}{l}\text { Peserta semakin memahami tata cara, tip dan trik maintenance pada } \\
\text { sistem komputer, melakukan manajemen dan perkiraan kejadian } \\
\text { kerusakan sehingga dapat meminimalisir kerugian akibat kerusakan. }\end{array}$ \\
\hline Pengantar troubleshooting & $\begin{array}{l}\text { Peserta mampu memahami segala kerusakan awal yang diakibatkan } \\
\text { oleh kelemahan sistem perangkat keras atau perangkat lunak, } \\
\text { sehingga kelemahan sistem komputer bisa diantisipasi dengan lebih } \\
\text { dulu melakukan pergantian hardware yang lemah. }\end{array}$ \\
\hline Praktek dan Istalasi & $\begin{array}{l}\text { Peserta mampu mengganti dan meng upgrade sistem atau perangkat } \\
\text { yang rusak, mampu melakukan instalasi software-software yang } \\
\text { cras atau yang memerlukan upgrade. }\end{array}$ \\
\hline Penutup & $\begin{array}{l}\text { hasilnya pemahaman peserta menjadi lebih baik dan lebih menguasi } \\
\text { maintenance, troubleshooting bahkan instalasi sistem komputer. }\end{array}$ \\
\hline
\end{tabular}

Bisa di pahami hasil dari kegiatan pengabdian yang dilakukan ini softskills para peserta siswa dan siswi yang mengikuti pelatihan meningkat dengan sangat baik dan pelatihan berhasil dengan sangat baik, sehingga peserta pelatihan menjadi lebih optimis dalam menghadapi masa depannya ini memberikan keuntungan bagi SMKN 3 Kab. Lahat karena masyarakat semakin percaya dan bagi STTP dengan pengabdian dan pelatihan ini mendapat calon atau peminat baru untuk kuliah di STTP dan lebih meningkatkan kepercayaan pada kemampuan alumni yang sangat baik, sehingga bisa diidentifikasi berikut merupakan hasil akhirnya, yaitu:

a. Peserta siswa/siswi SMKN 3 Kab. Lahat mempunyai pengetahuan dan pemahaman yang baik tentang maintenance dan troubleshooting pada sistem komputer.

b. Seluruh siswa/siswi SMKN $3 \mathrm{Kab}$. Lahat menjadi sangat paham terhadap teknologi informasi yang lebih aplikatif untuk mendukung dalam pengolahan data yang diperlukannya, menggunakan sistem computer handal.

c. Guru SMKN $3 \mathrm{Kab}$. Lahat sudah terbantu dalam pemberian pemahaman terhadap teknologi informasi up to date yang aplikatif.

d. Para siswa/siswi peserta pelatihan lebih memahami lagi tentang aplikasi pembelajaran TIK yang disampaikan oleh guru didalam kelas, jauh lebih memahami secara lebih aplikatif dalam maintenance. 
e. Para siswa/siswi peserta pelatihan menjadi lebih merasa percaya diri saat terjun di dunia kerja dan lebih memiliki pemahaman pada siswa/siswi yang melanjutkan studi keperguruan tinggi jelas pembelajaran ini menjadi pemahaman awal pada bergaul di perkuliahan di kampus.

\section{KESIMPULAN}

Dari pelaksanaan pengabdian masyarakat ini yang dilakukan di SMKN 3 Kab. Lahat dengan tujuan melatih siswa/siswi dalam melakukan maintenance dan troubleshooting sistem komputer didapatkan kesimpulan sebagai berikut:

a. Proses pembelajaran dengan cara belajar secara langsung praktek ternyata sudah mampu meningkatkan semangat siswa belajar menjadi lebih giat.

b. Menambah softskills siswa/siswi SMKN $3 \mathrm{Kab}$. Lahat dalam bidang maintenance dan trouble shooting sistem komputer menjadi sangat baik.

c. Meningkatnya rasa kepercayaan diri siswa dengan kemampuannya ketika terjun di masyarakat, karena pemahamannya dalam teknologi yang aplikatif.

d. Sangat membantu para guru pelajaran mata pelajaran dalam hal memahamkan siswa terhadap suatu aplikasi tertentu dalam maintenance.

\section{SARAN}

Maka sesuai dengan pengalaman yang dilihat dan dirasakan penulis/pengabdi saat melakukan pengabdian $(\mathrm{PkM})$ ini maka, penulis dalam hal ini bisa memberikan saran:

a. Waktu pelaksanaan kegiatan pelatihan untuk hal yang komplek pleksibel, agar materi benarbenar tersampaikan dengan baik dan benar.

b. Tempat pengabdia atau instansi binaan ditambah.

c. Sarana pendukung PkM

d. Koordinasi harus lebih baik antar peserta, dilakukan dengan sosialisasi lebih baik.

\section{UCAPAN TERIMA KASIH}

Terima kasih STTP, SMKN 3 Lahat, dan Peserta Pelatihan, semoga apa yang sudah dilakukan menjadi amal dan pahala yang memiliki nilai dimata yang maha kuasa.

\section{DAFTAR PUSTAKA}

[1] Muslim, B. 2018. Pelatihan aplikasi editing video dengan filmora., Laporan Pengabdian Kepada Masyarakat, LPPM STT Pagaralam.

[2] Hutchinson E. Sarah and Sawyer C. Stacey, 2000, Computers, Communications \& Information, McGraw Hill Companies Inc.

[3] Indonesia Services Education HP Tim, 2001, Manajemen Sistem Belajar Di Dunia Maya, Majalah Info Komputer.

[4] Muslim, B. 2018. Pelatihan Pembuatan Blog Bagi Guru Ma Ponpes Darul Mutaqin Kota Pagaralam. NGABDIMAS. Vol 1. No.1. Bulan Juni, Hal. 6-11

[5] B. Muslim, Pengantar teknologi informasi. Yogyakarta: Deepublish, 2017.

[6] Horsley, M., Knight, B., \& Huntly, H. 2010. The role of textbooks and other teaching and learning resources in higher education in Australia: Change and continuity in supporting learning. IARTEM 1-Journal. 3(2). 43-61.

[7] Muslim, B. (2018). Analisis system informasi (SI) terintegrasi di Perguruan Tinggi (PT) (Studi Kasus: STT Pagaralam). Jurnal Teknologi Informasi MURA, Vol 10. Page 83-91.

[8] Muslim, B (2014). Analisis rencana aplikasi teknologi informasi pada STT Pagar Alam. Proseding semnastik dan Magma. Issue: Aplikasi Teknologi dan sistem Informasi. PPP UBD Pres. Pages 397-404.

[9] M.H Jogiyanto, 1995, Pengenalan Komputer, Andi Offset Yogyakarta. 
[10] Sadiman, A.S., Rahardjo, R., Haryono, A., \& Rahardjito. 2006. Media pendidikan: Pengertian, pengembangan, dan pemanfaatan. Jakarta: Rajagrafindo Persada.

[11] Menristekdikti. 2016. Panduan Pelaksanaan Penelitian dan Pengabdian Masyarakat di Perguruan Tinggi Edisi X Tahun 2016. hlm. 4 